\title{
Plasma-immersion ion implantation: A path to lower the annealing temperature of implanted boron emitters and simplify PERT solar cell processing
}

\author{
Adeline Lanterne $^{1,2}$ (D) | Thibaut Desrues ${ }^{1,2}$ | Coralie Lorfeuvre ${ }^{1,2}$ | Marianne Coig ${ }^{1,3}$ | \\ Frank Torregrosa $^{4}$ | Frédéric Milési ${ }^{1,3}$ | Laurent Roux ${ }^{4}$ | Sébastien Dubois ${ }^{1,2}$
}

${ }^{1}$ University Grenoble Alpes, Grenoble F38000, France

${ }^{2}$ CEA, Liten, INES, 50 Avenue du Lac Léman, Le Bourget-du-Lac 73375, France

${ }^{3}$ CEA, Leti, MINATEC Campus, 17 rue des Martyrs, Grenoble 38054, France

${ }^{4}$ IBS, Rue Gaston Imbert Prolongée, Z.I. Rousset-Peynier, Peynier 13790, France

\section{Correspondence}

Adeline Lanterne, University Grenoble Alpes, CEA, Liten, Solar Technologies Department Grenoble F-38000, France.

Email: adeline.lanterne@cea.fr

Funding information

FUI; Bpifrance

\begin{abstract}
Ion implantation is a suitable and promising solution for the massive industrialization of boron doping, which is a crucial process step for most next-generation solar cells based on crystalline silicon (c-Si). However, the use of ion implantation for boron doping is limited by the high temperature (in the $1050^{\circ} \mathrm{C}$ range) of the subsequent activation anneal, which is essential to dissolve the boron clusters and reach a high-emitter quality. In this work, we propose the use of plasma-immersion ion implantation (PIII) from $\mathrm{B}_{2} \mathrm{H}_{6}$ gas precursor instead of the standard beamline ion implantation (BLII) technique to decrease this temperature down to $950^{\circ} \mathrm{C}$. PIII and BLII boron emitters were compared with annealing temperatures ranging from $950^{\circ} \mathrm{C}$ to $1050^{\circ} \mathrm{C}$. Contrary to BLII, no degradation of the emitter quality was observed with PIII implants annealed at $950^{\circ} \mathrm{C}$ along with a full activation of the dopants in the emitter. At $1000^{\circ} \mathrm{C}$, emitter saturation current densities $\left(J_{\text {oe }}\right)$ below $21 \mathrm{fA} / \mathrm{cm}^{2}$ were obtained using the PIII technique regardless of the tested implantation doses for sheet resistances between 110 and $160 \Omega /$ sq. After metallization steps, the metal/emitter contact resistances were assessed, indicating that these emitters were compatible with a conventional metallization by screenprinting/firing. The PIII boron emitters' performances were further tested with their integration in n-type passivated emitter rear totally diffused (PERT) solar cells fully doped by PIII. Promising results already show a conversion efficiency of $20.8 \%$ using a lower annealing temperature than with BLII and a reduced production cost.
\end{abstract}

\section{KEYWORDS}

annealing temperature, $\mathrm{B}_{2} \mathrm{H}_{6}$ plasma, boron doping, $\mathrm{n}$-type PERT solar cells, plasma-immersion ion implantation, silicon solar cells

We report a new way to activate implanted boron emitter at low temperature that is the use of plasma-immersion ion implantation (PIII) from $\mathrm{B}_{2} \mathrm{H}_{6}$ plasma. $\mathrm{A}$ full activation of the emitter at $950^{\circ} \mathrm{C}$ was observed even for a high implantation dose corresponding to a sheet resistance of $112 \Omega /$ sq. Promising performances while being integrated in n-PERT solar cells fully doped by PIII were demonstrated with efficiency of $20.8 \%$. 


\section{1 | INTRODUCTION}

The fast evolution and wide range of crystalline silicon (c-Si) solar cell structures, presently under active researches, challenge the prediction of the future industrial transfers that will follow the current switch toward passivated emitter and rear solar cell (PERC). ${ }^{1}$ However, near all the considered architectures, such as passivated emitter rear locally diffused (PERL) cell, passivated emitter rear totally diffused (PERT) cell, or interdigitated back contact (IBC) solar cell, with or without passivated contacts, have in common the integration of boron-doped layers. Moreover, boron doping is essential for $n$-type silicon-based solar cells, which still demonstrate the highest efficiency potential today. ${ }^{2}$ Finding a suitable industrial solution for the boron doping is currently one of the keys for the massive industrialization of these nextgeneration solar cells.

Nowadays, high-temperature gaseous diffusion from $\mathrm{BBr}_{3}$ or $\mathrm{BCl}_{3}$ precursors is the main technique used for boron doping. High photovoltaic (PV) conversion efficiencies can be reached by this way with recently $20.8 \%$ obtained on a pilot line of screen-printed $n$-type PERT (n-PERT) solar cells. ${ }^{3}$ However, a keen interest toward singleside doping techniques has been seen these past few years. ${ }^{4}$ Compared with the double-side doping of the $\mathrm{BBr}_{3}$ and $\mathrm{BCl}_{3}$ diffusions, they can strongly simplify the solar cells process flows and thus reduce the production cost of solar cells with boron-doped layers. Most of them have demonstrated high boron emitter electrical qualities such as spin-on coating, ${ }^{5}$ screen printing, ${ }^{4}$ codiffusion from atmospheric pressure chemical vapor deposition (APCVD) of doped layers, ${ }^{6}$ and ion implantation. ${ }^{7}$ Some of these single-side doping techniques are already used in high-efficiency n-type solar cells., ${ }^{8,9}$

Among these techniques, this paper focuses on ion implantation, which presents other advantages as the possibility of local doping thanks to an in situ masking ${ }^{10}$ that can strongly simplify the process flow of selective emitters and IBC cells, the ability to easily and precisely control the dopant concentration and distribution as well as the high uniformity and reproducibility of the doping. ${ }^{11}$ In addition, very high-emitter quality has been reported using a beamline ion implantation (BLII) of $\mathrm{B}^{+}$ions, with emitter saturation current densities $\left(\mathrm{J}_{\mathrm{Oe}}\right)$ lower than $40 \mathrm{fA} / \mathrm{cm}^{2},{ }^{12}$ along with promising PV conversion efficiencies up to $21.8 \%$ with screen-printed n-PERT cells. ${ }^{7}$

However, the main drawback of $\mathrm{B}^{+}$implantations by the standard BLII technique remains the high annealing temperature $\left(\geq 1050^{\circ} \mathrm{C}\right)$ necessary to remove the induced crystal defects as dislocation loops and boron interstitial clusters (BICs) $)^{13,14}$ and thus achieve low $J_{0 e}$ values. ${ }^{15}$ This high-temperature treatment can affect the bulk charge carrier lifetime of Czochralski $(C z)$ wafers by the formation of oxygen-related defects and by increasing the risk of parasitic contamination (eg, from the furnace). This high-thermal budget also leads to deep emitter profiles and to an increased processing cost. To solve this issue, two approaches have been previously reported. The first, investigated by J. Krügener et al, uses the implantation of $\mathrm{BF}^{2+}$ ions instead of $\mathrm{B}^{+}$to reduce the activation annealing temperature thanks to an amorphization of the silicon surface. ${ }^{12}$ Activation temperatures as low as $950^{\circ} \mathrm{C}$ have been successfully tested, but the solar cell performances are reduced compared with $\mathrm{B}^{+}$implants. ${ }^{7}$ The second approach, reported by R. Müller et al, aims at using a very low implantation energy (1-5 keV) to locate the defects closer to the front surface, combined (after the activation step) with a chemical etch back of the first 35 to $85 \mathrm{~nm}$ of the boron emitter. ${ }^{16}$

In this work, we studied a third way to activate boron-implanted emitters at temperatures below $1050^{\circ} \mathrm{C}$, the use of plasma-immersion ion implantation (PIII) from $\mathrm{B}_{2} \mathrm{H}_{6}$ gas precursor. The PIII technique, which presents advantages in capital investment and running cost compared with BLII, ${ }^{17}$ also leads to a different as-implanted B concentration ([B]) profile. Whereas BLII implants monoenergetic ions resulting in a Gaussian-type $[\mathrm{B}]$ profile, where the depth of the $[\mathrm{B}]$ peak directly depends on the implantation energy, PIII can be considered as a multienergetic implant. Indeed, the wafer is directly immersed in the ionic bath where many collisions occur. As a consequence, the dopant concentration profile is shallower (for similar implantation dose and acceleration voltage) and exhibits a maximum always located at the surface level (cf Figure 1). Even if after annealing, a similar doping profile can be obtained, the shallower as-implanted dopants and defects profiles obtained by PIII should allow an easier defect recovery and thus a higher quality of the junction.

The paper aims at comparing BLII and PIII techniques for the boron emitter formation with activation annealing temperatures ranging from $950^{\circ} \mathrm{C}$ to $1050^{\circ} \mathrm{C}$. The results include a detailed analysis of the inactive $[B]$, followed by a discussion of the electrical performance variations. The impact of the implantation dose was later studied in the case of PIII implants allowing to compare various emitter sheet resistances. The study also aims at exploring the potential of PIII boron emitters for n-PERT silicon solar cells. Therefore, the contact on these emitters by a conventional screen-printed paste was investigated, and n-PERT silicon solar cells, fully doped by the PIII technique, were processed.

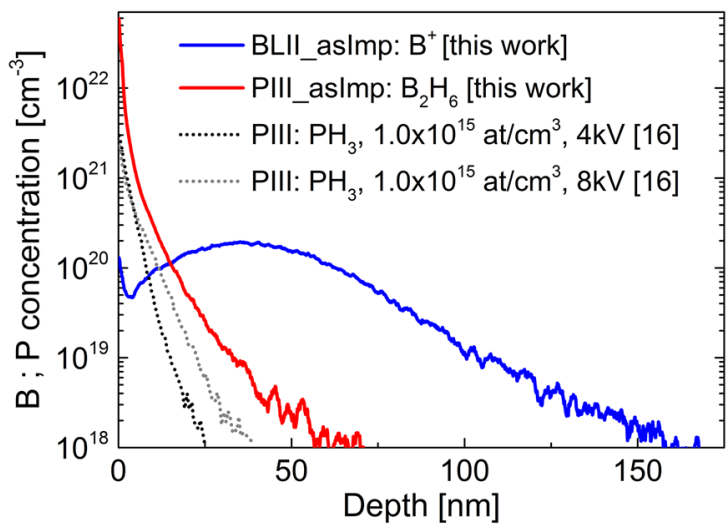

FIGURE 1 As-implanted boron and phosphorus concentration profiles measured by secondary-ion mass spectroscopy (SIMS).

Gaussian profile of beamline ion implantation (BLII) implant of $\mathrm{B}^{+}$ions at $10 \mathrm{keV}$ and $1.2 \times 10^{15} \mathrm{at} / \mathrm{cm}^{2}$ (BLII_asImp) compared with plasmaimmersion ion implantation (PIII) implants from $\mathrm{B}_{2} \mathrm{H}_{6}$ and $\mathrm{PH}_{3}$ gas precursors with two different implantation energies in the $\mathrm{PH}_{3}$ case, 4 and $8 \mathrm{kV}$ (SIMS from Michel et $\mathrm{al}^{18}$ ) [Colour figure can be viewed at wileyonlinelibrary.com] 


\section{2 | MATERIAL AND METHODS}

\section{1 | Study of implanted boron emitter}

Polished samples were used to study the [B] profile and boron activation rate after the annealing of BLII and PIII implantations. n-type $C z$ silicon $239-\mathrm{cm}^{2}$ wafers were used for the process of eight different samples, summarized in Table 1. After the wafer polishing in a $\mathrm{KOH}$ solution, boron ions were implanted on the front side by the BLII (using a VIISTA ${ }^{\circledR}$ beamline ion implanter from AMAT) or the PIII (using PULSION-SOLAR® tool from IBS) technique. In the case of $\mathrm{BLII}, \mathrm{B}^{+}$ions were implanted at $10 \mathrm{keV}$ with an implantation dose of $1.2 \times 10^{15} \mathrm{at} / \mathrm{cm}^{2}$. For the PIII technique, different doses (from 1 $\times 10^{15}$ to $5.5 \times 10^{15} / \mathrm{cm}^{2}$ ) were implanted from a $\mathrm{B}_{2} \mathrm{H}_{6}$ plasma.

Notice that for the PIII technique, the total implanted ions dose (called machine dose) differs from the boron-implanted dose as the first sums all the implanted ions from the $\mathrm{B}_{2} \mathrm{H}_{6}$ plasma $\left(\mathrm{B}^{+}, \mathrm{H}^{+}\right.$, $\mathrm{B}_{2} \mathrm{H}_{\mathrm{x}<6}{ }^{+}$, and $\mathrm{BH}_{\mathrm{x}}{ }^{+}$ions). Depending on the plasma parameters, which can change the complexes dissociation, an identical machine dose can correspond to different boron doses. In this study, two different plasma conditions were used. For the sake of clarity, the machine doses of the first plasma will be noted as multiple of $D_{0}$, and the machine doses of the second plasma will be noted as multiple of $D_{1}$. $D_{0}$ and $D_{1}$ correspond to the same $1 \times 10^{15} \mathrm{~cm}^{-2}$ total implanted ions dose but to different implanted boron doses.

To activate the implanted boron, an anneal in a standard horizontal oxidation furnace was performed under $\mathrm{N}_{2}$ with a plateau of 5 minutes at $1050^{\circ} \mathrm{C}$ or 30 minutes at $950^{\circ} \mathrm{C}$, followed or not by an in situ thermal oxidation step at lower temperature $\left(720^{\circ} \mathrm{C}\right)$. The total [B] profiles were obtained by secondary-ion mass spectroscopy (SIMS) measurements following the implantation step (see Figure 1) and following the activation annealing. The oxygen signal was also recorded to estimate the $\mathrm{SiO}_{2}$ thickness at the surface. Electrochemical capacitance voltage (ECV) measurements were conducted on the annealed samples after an Hydrofluoric acid (HF) dip to remove the native or grown oxide on the surface. ECV measurements were performed using a WEP CVP21 profiler with a 0.1M solution of $\mathrm{NH}_{4} \mathrm{~F}$. The etch area was corrected based on external etch area measurements. In this study, the carrier concentration measured by $E C V$ is supposed to be equivalent to the electrically active [B].

Textured samples were used to investigate the carrier recombination activity of BLII and PIII boron emitters. For this purpose, nine batches of samples were studied, namely, BLII_C, BLII_D, and BLII_E for BLII implantation and PIII_C to PIII_J for PIII samples. The process details of each batch are summarized in Table 2.

Samples were processed from n-type $C z 239-\mathrm{cm}^{2}$ wafers of 3 to 5 $\Omega . c m$ resistivity (sister wafers were used, from the same part of the ingot). They were first randomly textured and cleaned with an RCA step. In the three BLII batches, $\mathrm{B}^{+}$ions were implanted on both sides with a dose of $2 \times 10^{15} \mathrm{at} / \mathrm{cm}^{2}$ while the six PIII batches were implanted on both sides using $\mathrm{B}_{2} \mathrm{H}_{6}$ plasma and an implantation dose of $5 \times D_{1}$. Both implantation conditions were chosen to reach similar emitter sheet resistance ( $R_{\text {sheet }}$ ) of approximately $90 \Omega /$ sq after an annealing at $1050^{\circ} \mathrm{C}$. In total, three annealing schemes were tested for each implantation technique with a plateau of 5 minutes at $1050^{\circ} \mathrm{C}$, of 15 minutes at $1000^{\circ} \mathrm{C}$, and of 30 minutes at $950^{\circ} \mathrm{C}$. The annealing also includes an in situ thermal oxidation step at the end at $720^{\circ} \mathrm{C}$. It was followed by an HF dip to remove the silicon oxide. In addition, samples from three batches (PIII_H, PIII_I, and PIII_J) were further etched before passivation. The etching process consists in an oxidation of the surface by an additional and longer thermal oxidation, followed by an $\mathrm{HF}$ dip to etch the formed $\mathrm{SiO}_{x}$ layer. The oxidation time was adjusted to etch 50 to $60 \mathrm{~nm}$ of the emitter. All the samples were then passivated by $5 \mathrm{~nm}$ of $\mathrm{Al}_{2} \mathrm{O}_{3}$ deposited on each side by thermal atomic layer deposition (ALD) and $70 \mathrm{~nm}$ of $\mathrm{SiN}_{\mathrm{x}}: \mathrm{H}$ deposited by plasma-enhanced chemical vapor deposition (PECVD).

Electrical performances were assessed after an infrared (IR) firing in a belt furnace by the inductively coupled quasi-steady-state photoconductance decay method (IC-QssPC) on a Sinton WCT-120 lifetime tester. Implied open-circuit voltage $\left(\mathrm{i}_{\mathrm{oc}}\right)$ was acquired at one sun, and the $J_{0 e}$ was extracted from the carrier lifetime measurement with the method used on the WCT- $120^{19}$ based on the intrinsic lifetime parametrization by Richter et $\mathrm{al}^{20}$ and on the band-gapnarrowing model from Schenk. ${ }^{21}$ It was applied on an injection density $(\Delta \mathrm{n})$ range of $30 \%$ of $2 \times 10^{16} / \mathrm{cm}^{3}$. The active $[B]$ was then obtained by ECV profiling after an HF dip to remove the passivation layers. The

TABLE 1 Summary of the processes performed on the samples together with the extracted oxide thickness and measured $R_{\text {sheet }}$ values

\begin{tabular}{|c|c|c|c|c|c|c|c|}
\hline $\begin{array}{l}\text { Sample } \\
\text { Name }\end{array}$ & Substrate & Implant & Implantation Dose $\left(\mathrm{at} / \mathrm{cm}^{3}\right)$ & $\begin{array}{l}\text { Annealing Temperature } \\
\left({ }^{\circ} \mathrm{C}\right)\end{array}$ & $\begin{array}{l}\text { Oxidation } \\
\text { Step }\end{array}$ & $\begin{array}{l}\text { Oxide Thickness } \\
\text { (nm) }\end{array}$ & $R_{\text {sheet }}(\Omega / s q)$ \\
\hline BLII_asImp & \multirow{2}{*}{$\begin{array}{l}\text { n-type } \\
\text { Cz 239- } \mathrm{cm}^{2} \\
\text { wafers }\end{array}$} & BLII: $\mathrm{B}^{+}$ & $1.2 \times 10^{15}$ & - & - & - & - \\
\hline BLII_B & & BLII: $\mathrm{B}^{+}$ & $1.2 \times 10^{15}$ & 950 & Yes & 11 & 111 \\
\hline PIII_asImp & \multirow[t]{4}{*}{$\mathrm{KOH}$ polished } & PIII: $\mathrm{B}_{2} \mathrm{H}_{6}$ & $\mathrm{D}_{0}$ & - & - & - & - \\
\hline PIII_B & & PIII: $\mathrm{B}_{2} \mathrm{H}_{6}$ & $\mathrm{D}_{0}$ & 950 & Yes & 14 & 145 \\
\hline PIII_C & & PIII: $\mathrm{B}_{2} \mathrm{H}_{6}$ & $3 \times D_{0}$ & 950 & Yes & 15 & 112 \\
\hline PIII_D & & PIII: $\mathrm{B}_{2} \mathrm{H}_{6}$ & $3 \times D_{0}$ & 950 & No & 4 & 106 \\
\hline
\end{tabular}

Abbreviations: BLII, beamline ion implantation; PIII, plasma-immersion ion implantation. 
TABLE 2 Summary of the processes performed on the nine samples batches together with the average $R_{\text {sheet }}$

\begin{tabular}{|c|c|c|c|c|c|c|c|}
\hline $\begin{array}{l}\text { Batch } \\
\text { Name }\end{array}$ & Substrate & Implant & Implantation Dose $\left(\mathrm{at} / \mathrm{cm}^{3}\right)$ & $\begin{array}{l}\text { Annealing Temperature } \\
\left({ }^{\circ} \mathrm{C}\right)\end{array}$ & $\begin{array}{l}\text { Oxidation } \\
\text { Step }\end{array}$ & Etching & $R_{\text {sheet }}(\Omega / s q)$ \\
\hline BLII_C & \multirow{2}{*}{$\begin{array}{l}\text { n-type } \\
\text { Cz 239- } \mathrm{cm}^{2} \\
\text { wafers }\end{array}$} & BLII: $\mathrm{B}^{+}$ & $2 \times 10^{15}$ & 1050 & Yes & No & 97 \\
\hline BLII_E & & BLII: $B^{+}$ & $2 \times 10^{15}$ & 950 & Yes & No & 112 \\
\hline PIII_E & 3-5 $\Omega . c m$ & PIII: $\mathrm{B}_{2} \mathrm{H}_{6}$ & $5 \times \mathrm{D}_{1}$ & 1050 & Yes & No & 89 \\
\hline PIII_G & \multirow{4}{*}{$\mathrm{KOH}$ textured } & PIII: $\mathrm{B}_{2} \mathrm{H}_{6}$ & $5 \times \mathrm{D}_{1}$ & 950 & Yes & No & 180 \\
\hline PIII_H & & PIII: $\mathrm{B}_{2} \mathrm{H}_{6}$ & $5 \times \mathrm{D}_{1}$ & 1050 & Yes & Yes & 93 \\
\hline PIII_I & & PIII: $\mathrm{B}_{2} \mathrm{H}_{6}$ & $5 \times \mathrm{D}_{1}$ & 1000 & Yes & Yes & 129 \\
\hline PIII_J & & PIII: $\mathrm{B}_{2} \mathrm{H}_{6}$ & $5 \times D_{1}$ & 950 & Yes & Yes & 203 \\
\hline
\end{tabular}

Abbreviations: BLII, beamline ion implantation; PIII, plasma-immersion ion implantation.

ECV profiles were acquired using an area factor of 1.64 on these textured samples. The ECV profiles were then corrected by modifying the area factor until the calculated sheet resistance of the ECV doping profile matches the emitter sheet resistance measured by the four-point probe method.

At last, the impact of the implantation/annealing conditions on the metal/c-Si contact resistance of these emitters was investigated. A standard commercial $\mathrm{Ag} / \mathrm{Al}$ paste was screen printed on the samples from the PIII batches, and the contact resistivity was assessed by the transmission line model (TLM) technique ${ }^{22}$ on a GP Solar tool after an IR firing step.

Additional symmetrical $\mathrm{SiN}_{\mathrm{x}} / \mathrm{Al}_{2} \mathrm{O}_{3} / \mathrm{p}^{+} / \mathrm{n} / \mathrm{p}^{+} / \mathrm{Al}_{2} \mathrm{O}_{3} / \mathrm{SiN}_{\mathrm{x}}$ samples were similarly processed to compare several emitter sheet resistances. They were implanted by PIII from a $\mathrm{B}_{2} \mathrm{H}_{6}$ plasma at various implantation doses from $0.8 \times D_{0}$ to $5.5 \times D_{0}$. Samples were later annealed with peak temperatures ranging from $920^{\circ} \mathrm{C}$ to $1050^{\circ} \mathrm{C}$. In this study, the oxidation step was removed from the annealing on three batches:

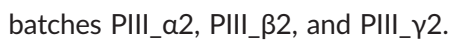

\section{2 | Solar cells process}

n-type PERT solar cells fully (front and rear surfaces) doped by PIII were fabricated following two industrial process flows, noted "separated anneals" and "coanneal." For these two process flows, n-type Cz wafers (resistivity $\sim 1 \Omega . \mathrm{cm}$ ) were first textured in a $\mathrm{KOH}$ solution, followed by an RCA cleaning. Boron was then implanted on the front side by PIII from $\mathrm{B}_{2} \mathrm{H}_{6}$ plasma, and phosphorus was implanted on the back side also by PIII but from $\mathrm{PH}_{3}$ plasma. In the coanneal case, boron and phosphorus dopants were activated in a single thermal process performed in a horizontal oxidation furnace with a high-temperature step at $950^{\circ} \mathrm{C}$ under $\mathrm{N}_{2}$, followed by an in situ thermal oxidation step. In the separated anneals process, a first anneal at $1000^{\circ} \mathrm{C}$ or $950^{\circ} \mathrm{C}$ including an in situ thermal oxidation was used to activate the boron dopants, and then, a second anneal with a peak temperature below $900^{\circ} \mathrm{C}$ in $\mathrm{N}_{2}$ atmosphere was used for the phosphorus dopants. The boron implantation dose was adjusted to obtain an $R_{\text {sheet }}$ close to $110 \Omega$ /sq after both $950^{\circ} \mathrm{C}$ and $1000^{\circ} \mathrm{C}$ anneals. And the phosphorus implantation dose was chosen to obtain a back surface field (BSF) $R_{\text {sheet }}$ of $45 \Omega / s q$ after the coannealing at $950^{\circ} \mathrm{C}$ and a $90-\Omega / \mathrm{sq}$ BSF in the separated anneals process. The boron-doped emitter was passivated by an $\mathrm{Al}_{2} \mathrm{O}_{3} / \mathrm{SiN}_{x}$ stack, and the phosphorus-doped BSF was passivated by a $\mathrm{SiN}_{x}$ layer. The metallization grids were screen printed on each side with commercial $\mathrm{Ag} / \mathrm{Al}$ and $\mathrm{Ag}$ pastes on the front and rear sides, respectively, with four full bus bars. The results of two batches are reported: the first with a nonspecifically optimized metallization grid leading to fingers widths of 50 to $55 \mu \mathrm{m}$ and the second with a first optimization level leading to fingers widths of $45 \mu \mathrm{m}$, both widths measured after firing. The solar cells were finally fired in an IR belt furnace followed by a laser junction opening.

\section{3 | RESULTS AND DISCUSSION}

\section{1 | Comparison of BLII and PIII boron emitters}

\subsection{1 | Boron activation: Results on polished samples}

As previously mentioned, BICs, inactive boron, or other extended defects can be found in the implanted boron emitter after the activation annealing, when the thermal budget is not high enough. With the goal to see if there are some variations in the inactive boron quantity between BLII and PIII techniques, SIMS and ECV analyses were compared. Two thermal anneals were studied: the first with a peak temperature at $1050^{\circ} \mathrm{C}$ and the second at $950^{\circ} \mathrm{C}$. Table 1 summarizes the eight samples investigated for this purpose with the oxide thickness extracted from the oxygen signal of the SIMS measurement and the emitter $\mathrm{R}_{\text {sheet }}$ measured by the four-point probe method.

In the BLII case, the $\mathrm{B}^{+}$ion implantation dose conducts to an emitter sheet resistance of $101 \Omega /$ sq after an anneal at $1050^{\circ} \mathrm{C}$ and to 111 $\Omega /$ sq after an anneal at $950^{\circ} \mathrm{C}$; both anneals include an oxidation step. The boron distribution measured by SIMS after implantation can be seen in Figure 1 with the BLII_asImp sample. The [B] profiles extracted from the SIMS and ECV measurements after the heat treatments at $1050^{\circ} \mathrm{C}$ and $950^{\circ} \mathrm{C}$ are shown in Figure 2. 
As seen in Figure 2A, the SIMS and ECV measurements of $[B]$ for the sample annealed at $1050^{\circ} \mathrm{C}$ are identical. This indicates the possibility of a full activation of the implanted boron in this $101 \Omega / \mathrm{sq} \mathrm{BLII}$ emitter because of the absence of differences between the activated and the total $[\mathrm{B}]$ profiles.

In Figure 2B, it can be seen that lowering the activation temperature to $950^{\circ} \mathrm{C}$ introduces a gap between the SIMS and ECV curves for depths ranging from 30 to $100 \mathrm{~nm}$. The space between both curves corresponds to the inactive boron dose. As previously discussed, this inactive boron dose seems to be explained by the presence of BICs in the emitter. ${ }^{13,14}$ It was reported that the BICs are rapidly formed at the beginning of the annealing and once grown become immobile and hard to dissolve during further anneals. ${ }^{23}$ The good correlation between the location of the inactive boron of sample BLII_B and the region where the as-implanted [B] (BLII_asImp curve in Figure $2 \mathrm{~B}$ ) exceeds the boron solubility limit at $950^{\circ} \mathrm{C}$ (ie, $\sim 9 \times 10^{19} / \mathrm{cm}^{3}$ ), ${ }^{24}$ further supports the immobile BICs hypothesis. For comparison, the solubility limit ${ }^{24}$ at $1050^{\circ} \mathrm{C}$ is of $1.5 \times 10^{20} / \mathrm{cm}^{3}$.

The case of PIII boron emitters can be discussed with PIII_A and PIII_B samples of Table 1, also characterized in Figure 3. The implantation dose $D_{0}$ used on these PIII emitters results in an $R_{\text {sheet }}$ of $79 \Omega / s q$ after the anneal at $1050^{\circ} \mathrm{C}$ and in an $R_{\text {sheet }}$ of $145 \Omega / s q$ at $950^{\circ} \mathrm{C}$. A stronger increase of $R_{\text {sheet }}$ can be noted with the annealing temperature decrease to $950^{\circ} \mathrm{C}$ on these PIII emitters as compared with the previous BLII case.

Similarly to the BLII boron emitter, the perfect matching between SIMS and ECV curves at $1050^{\circ} \mathrm{C}$ (see Figure $3 \mathrm{~A}$ ) suggests a complete activation of the boron atoms in the emitter. If BLII_A and PIII_A are indeed fully activated, the lower $\mathrm{R}_{\text {sheet }}$ measured on the PIII emitter (79 $\Omega / \mathrm{sq}$ instead of $101 \Omega / \mathrm{sq}$ ) means that the $D_{0}$ dose used for the PIII sample corresponds to a higher boron-implanted dose than the $1.2 \times 10^{15}-$ at $/ \mathrm{cm}^{2}$ dose of the BLIl sample.

At $950^{\circ} \mathrm{C}$ in Figure 3B however, the SIMS curve of PIII_B differs from the BLII_B sample, as the bump between 30 to $100 \mathrm{~nm}$ of depth is no longer seen. A good correlation between the SIMS and ECV curves is observed for PIII_B despite the low annealing temperature. The PIII as-implanted profile is also displayed on Figure $3 \mathrm{~B}$ to locate the region where $[B]$ exceeds the solubility limit of boron at $950^{\circ} \mathrm{C}$ and thus where the BICs are the most likely to be formed. The PIII as-implanted boron distribution only exceeds $9 \times 10^{19} / \mathrm{cm}^{3}$ in the first $15 \mathrm{~nm}$ of the profile. As a result of the in situ oxidation step, most of this area will be after the activation annealing step located inside the $14 \mathrm{~nm}$ of $\mathrm{SiO}_{2}$ layer and not inside the emitter. This is a major difference with the BLII technique where the as-implanted $[B]$ exceeds the solubility limit at $950^{\circ} \mathrm{C}$ much deeper in the wafer (from 10 to $70 \mathrm{~nm}$ ). In the PIII emitter annealed at $950^{\circ} \mathrm{C}$, the "near-surface" location of the as-implanted maximum concentration and the growth of the silicon oxide that consumes most of the area where $[B]$ exceeds the solubility limit could explain the absence of BICs and consequently the full activation of the $B$ atoms within the emitter observed in Figure 3B. Even if the high voltage used for the PIII implantation increases, according to the as-implanted profile, the location where $[B]$ exceeds its $950^{\circ} \mathrm{C}$ solubility limit remains very close to the surface (see Figure 1 for the variation between 4 and $8 \mathrm{kV}$ ).
As the $R_{\text {sheet }}$ of this PIII_B sample is higher than the BLII_B sample, $145 \Omega /$ sq instead of $111 \Omega /$ sq, the implantation dose of PII boron emitter was increased to $3 \times D_{0}$ in samples PIII_C and PIII_D in order to compare emitters of similar $\mathrm{R}_{\text {sheet }}$. SIMS and ECV measurements of PIII_C sample annealed at $950^{\circ} \mathrm{C}$ and with a lower $R_{\text {sheet }}$ of $112 \Omega / s q$ are displayed on Figure 4A. Despite the increase of the PIII implantation dose that could enhance the possibility of BICs formation, a perfect matching of the SIMS and ECV curves is still observed for an emitter $R_{\text {sheet }}$ of $112 \Omega /$ sq.

Finally, the impact of the silicon oxide growth on the total and electrically active $[B]$ was studied with sample PIII_D, similarly processed than PIII_C, but without the oxidation step. Without the oxidation step, the main impact on the total $[B]$ profile (see Figure $4 B$ ) is the absence of the boron depletion previously observed at the $\mathrm{SiO}_{2} / \mathrm{Si}$ interface on the PIII_C sample. Moreover, without the oxidation step, in the first $20 \mathrm{~nm}$ below the surface, a gap between the SIMS and ECV curves can be observed that suggests the presence of inactive boron atoms in this area. The oxidation step seems then to be necessary to form a fully activated PIII boron emitter annealed at $950^{\circ} \mathrm{C}$.

\subsection{2 | Carrier recombination activity of the implanted boron emitters: Results on textured samples}

The variation of the boron emitter recombination activity between BLII and PIII techniques was investigated with nine different boron emitters with features summarized in Table 2, all passivated by an $\mathrm{Al}_{2} \mathrm{O}_{3} / \mathrm{SiN}_{\mathrm{x}}$ stack. The implantation dose was kept constant in this part for each implantation technique, and three annealing schemes were studied with peak temperatures at $1050^{\circ} \mathrm{C}, 1000^{\circ} \mathrm{C}$, and $950^{\circ} \mathrm{C}$. The two implants result in similar $\mathrm{R}_{\text {sheet }}$ after the $1050^{\circ} \mathrm{C}$ anneal with 89 and $97 \Omega / s q$ for PIII_E and BLII_C emitters, respectively. Lowering the temperature from $1050^{\circ} \mathrm{C}$ to $950^{\circ} \mathrm{C}$ increases the $R_{\text {sheet }}$ in all cases.

The activated $[B]$ profiles of the emitters described in Table 2 are shown in Figure 5. For BLII emitters (see Figure 5A), shorter junction depths and higher maximal $[B]$ are observed for lower annealing temperatures.

Regarding the PIII-related active [B] profiles (see Figure 5B), the maximum activated concentration is constant for all the annealing temperatures along with shorter junction depths for lower annealing temperatures, reminiscent of the $[B]$ profiles after an indiffusion from a deposited doped layer. ${ }^{25}$ Consequently, the total activated boron dose (integral of the ECV curve) strongly reduces in PIII between the $1050^{\circ} \mathrm{C}$ and the $950^{\circ} \mathrm{C}$ anneal with $1.2 \times 10^{15}$ and $5.9 \times 10^{14}$ at $/ \mathrm{cm}^{2}$, respectively. This drop of boron dose can explain the large increase of $R_{\text {sheet }}$ measured when the temperature decreases in the PIII case (seeTables 1 and 2). The missing boron dose at $950^{\circ} \mathrm{C}$ does not seem to be in an inactive state, as the SIMS concentration profile in Figure 4A shows a full activation of the emitter. We can however suspect that the missing dose is located inside the $\mathrm{SiO}_{2}$ layer as a higher $[\mathrm{B}]$ is measured inside it at $950^{\circ} \mathrm{C}$ than at $1050^{\circ} \mathrm{C}$ in Figure 3.

The $\mathrm{i}_{\mathrm{oc}}$ and $\mathrm{J}_{\mathrm{Oe}}$ measured on the boron emitters of Table 2 are displayed in Figure 6 . For a $1050^{\circ} \mathrm{C}$ peak temperature, similar $\mathrm{J}_{\mathrm{Oe}}$ and 
$\mathrm{iV}_{\text {oc }}$ values are determined for both implantation techniques, with $\mathrm{J}_{\mathrm{Oe}}$ below $35 \mathrm{fA} / \mathrm{cm}^{2}$ and $\mathrm{iV}_{\text {oc }}$ above $685 \mathrm{mV}$. However, at lower annealing temperatures, different behaviors are observed between PIII and BLII boron emitters. In agreement with the literature, for the BLII of $\mathrm{B}^{+}$ions, a strong drop in the $\mathrm{iV}_{\mathrm{oc}}$ value is observed when the temperature reduces from $1050^{\circ} \mathrm{C}$ to $950^{\circ} \mathrm{C}$, together with a large increase of the $\mathrm{J}_{\mathrm{Oe}}$. As reported before $\mathrm{e}^{15,26}$ and confirmed with this work (Figure 2), it mainly results from a higher inactive $[B]$.

A completely different trend is observed for PIII boron emitters where there is no degradation of the emitter quality for annealing at $1000^{\circ} \mathrm{C}$ and $950^{\circ} \mathrm{C}$ compared with the $1050^{\circ} \mathrm{C}$ case. A measurable improvement can even be noticed for temperatures below $1050^{\circ} \mathrm{C}$ for both parameters, $\mathrm{i}_{\text {oc }}$ and $\mathrm{J}_{\mathrm{Oe}}$. Further etching of the emitter (removing 50-60 nm as seen in Figure 5B) before passivation only slightly improves the $J_{\mathrm{Oe}}$ values. This is in agreement with the absence of implanted defects and a full activation of the boron in these PIII-doped emitters from $\mathrm{B}_{2} \mathrm{H}_{6}$ plasma even if annealed at $950^{\circ} \mathrm{C}$.

\subsection{Impact of the implantation dose on the PIII boron emitters properties}

In the above results, the PIII boron emitter quality was measured at $950^{\circ} \mathrm{C}$ only for a high-emitter $\mathrm{R}_{\text {sheet }}$ of $180 \Omega / \mathrm{sq}$. For a more accurate assessment of the PIII boron-doped emitters, the $R_{\text {sheet }}$ was varied by changing the implantation dose for several annealing schemes. The implantation doses used for each annealing peak temperature are detailed below.

- At $1050^{\circ} \mathrm{C}$, implantation doses ranging from $0.8 \times D_{0}$ to $1.6 \times D_{0}$ at $/ \mathrm{cm}^{2}$ were used, resulting in $R_{\text {sheet }}$ variations from 156 to $101 \Omega /$ sq
- At $1000^{\circ} \mathrm{C}$, implantation doses ranging from $1.1 \times D_{0}$ to $2.2 \times D_{0}$ at $/ \mathrm{cm}^{2}$ were used resulting in $\mathrm{R}_{\text {sheet }}$ variations from 157 to $110 \Omega /$ sq

- At $975^{\circ} \mathrm{C}$, implantation doses ranging from $1.6 \times D_{0}$ to $2 \times D_{0}$ at $/ \mathrm{cm}^{2}$ were used resulting in $R_{\text {sheet }}$ variations from 157 to $144 \Omega /$ sq

- At $950^{\circ} \mathrm{C}$, implantation doses ranging from $2 \times \mathrm{D}_{0}$ to $5.5 \times \mathrm{D}_{0}$ at $/ \mathrm{cm}^{2}$ were used resulting in $\mathrm{R}_{\text {sheet }}$ variations from 178 to 124 $\Omega /$ sq. Finally, the implantation dose $5.5 \times \mathrm{D}_{0}$ at $/ \mathrm{cm}^{2}$ corresponding to an $R_{\text {sheet }}$ of $185 \Omega$ /sq was performed with a peak temperature of $920^{\circ} \mathrm{C}$.

The corresponding $\mathrm{iV}_{\mathrm{oc}}$ and $\mathrm{J}_{\mathrm{Oe}}$ measurements are shown in Figure 7. Looking first at the $J_{0 e}$ results, very low values, below 21 $\mathrm{fA} / \mathrm{cm}^{2}$, were measured for annealing temperature at $975^{\circ} \mathrm{C}$ and above. This highlights and confirms the very high quality of these boron emitters, with a likely full recovery of implantation defects and that for all the implantation doses studied and $R_{\text {sheet }}$ from 100 to $160 \Omega$ /sq.

In the case of an annealing at $950^{\circ} \mathrm{C}$, the lowest $J_{0 e}$ value of 13 $\mathrm{fA} / \mathrm{cm}^{2}$ was determined for a $178 \Omega / \mathrm{sq}$ emitter with a corresponding $i \mathrm{~V}_{\text {oc }}$ value of $706 \mathrm{mV}$. While raising the implantation dose to $5.5 \times \mathrm{D}_{0}$ ( $R_{\text {sheet }}$ of $124 \Omega / s q$ ), an increase of $J_{0 e}$ is observed at $950^{\circ} \mathrm{C}$ that could be due to the remaining of some implantation damages for this high implantation dose or to the increasing contribution of Auger recombination in the emitter with the higher boron concentration (see Figures $3 \mathrm{~B}$ and $4 \mathrm{~A}$ as example of the boron concentration increase with higher implantation dose). Auger contribution to the $J_{0 \mathrm{e}}$ value was simulated on PV Lighthouse EDNA 2 calculator ${ }^{27}$ using the active $[\mathrm{B}]$ profile measured by ECV of these $950^{\circ} \mathrm{C}$ annealed emitters with $R_{\text {sheet }}$ of 178 and $124 \Omega$ /sq. The latest Auger parameterization by Richter et $\mathrm{al}^{28}$ was

TABLE $3 R_{\text {sheet }}, J_{0 e}$, and the simulated contribution of Auger recombination to the $J_{0 e}$ value noted $J_{0 e}$ Auger of PIII boron-doped emitters annealed at $950^{\circ} \mathrm{C}$

\begin{tabular}{lllllcr} 
Implant & Implantation Dose $\left(\mathrm{at} / \mathrm{cm}^{3}\right)$ & Annealing Temperature $\left({ }^{\circ} \mathrm{C}\right)$ & $\mathbf{R}_{\text {sheet }}(\Omega / \mathrm{sq})$ & $J_{\text {Oe }}\left(\mathrm{fA} / \mathrm{cm}^{2}\right)$ & $J_{\text {Oe_Auger }}\left(\mathrm{fA} / \mathrm{cm}^{2}\right)$ & $J_{\text {Oe_Auger }}(\%)$ \\
\hline PIII: $\mathrm{B}_{2} \mathrm{H}_{6}$ & $2.0 \times \mathrm{D}_{0}$ & 950 & 178 & 13 & 9.0 & 69 \\
\hline PIII: $\mathrm{B}_{2} \mathrm{H}_{6}$ & $5.5 \times \mathrm{D}_{0}$ & 950 & 124 & 54 & 16.8 & 31
\end{tabular}

Abbreviation: PIII, plasma-immersion ion implantation.

TABLE $4 \mathrm{R}_{\text {sheet }}$, $\mathrm{iV}_{\mathrm{oc}}$, and $\mathrm{J}_{\mathrm{Oe}}$ values of PIII boron-doped emitters passivated by an $\mathrm{Al}_{2} \mathrm{O}_{3} / \mathrm{SiN}_{\mathrm{x}}$ stack with and without the in situ oxidation step during the boron activation annealing

\begin{tabular}{|c|c|c|c|c|c|c|c|}
\hline Name & Implant & Implantation Dose $\left(\mathrm{at} / \mathrm{cm}^{3}\right)$ & Annealing Temperature $\left({ }^{\circ} \mathrm{C}\right)$ & Oxidation Step & $R_{\text {sheet }}(\Omega / s q)$ & $\mathrm{iV}_{\mathrm{oc}}(\mathrm{mV})$ & $\mathrm{J}_{\mathrm{Oe}}\left(\mathrm{fA} / \mathrm{cm}^{2}\right)$ \\
\hline PIII_a1 & PIII: $\mathrm{B}_{2} \mathrm{H}_{6}$ & $3.5 \times \mathrm{D}_{1}$ & 1050 & Yes & 101 & 693 & 20 \\
\hline PIII_a2 & PIII: $\mathrm{B}_{2} \mathrm{H}_{6}$ & $3.5 \times \mathrm{D}_{1}$ & 1050 & No & 97 & 677 & 25 \\
\hline PIII_ß1 & PIII: $\mathrm{B}_{2} \mathrm{H}_{6}$ & $4.8 \times \mathrm{D}_{1}$ & 1000 & Yes & 110 & 696 & 18 \\
\hline PIII_ß2 & PIII: $\mathrm{B}_{2} \mathrm{H}_{6}$ & $4.8 \times \mathrm{D}_{1}$ & 1000 & No & 106 & 688 & 28 \\
\hline PIII_Y1 & PIII: $\mathrm{B}_{2} \mathrm{H}_{6}$ & $12 \times D_{1}$ & 950 & Yes & 124 & 676 & 54 \\
\hline PIII_ү2 & PIII: $\mathrm{B}_{2} \mathrm{H}_{6}$ & $12 \times \mathrm{D}_{1}$ & 950 & No & 116 & 651 & 166 \\
\hline
\end{tabular}

Abbreviation: PIII, plasma-immersion ion implantation. 
a)

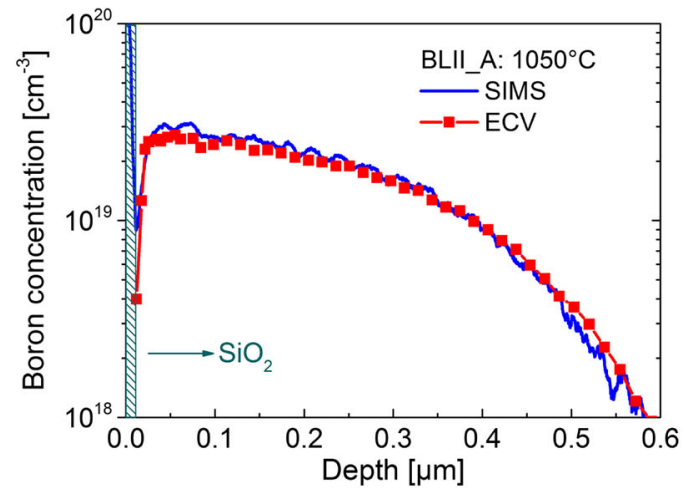

b)

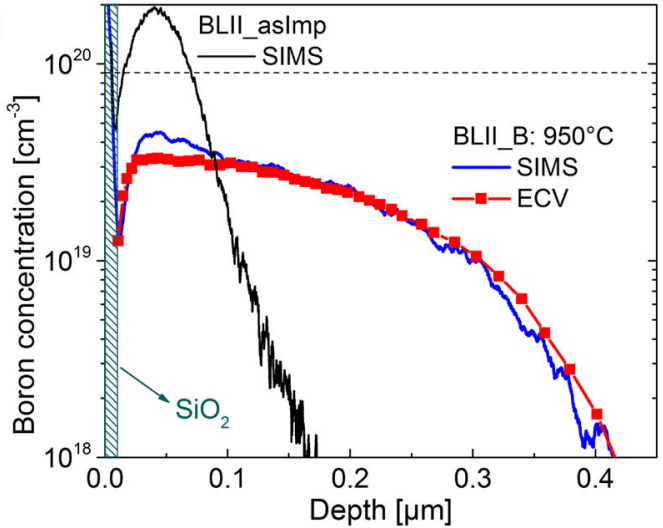

FIGURE 2 Boron concentration measured by secondary-ion mass spectroscopy (SIMS) and activated boron concentration obtained by electrochemical capacitance voltage (ECV) measurement of A, sample BLII_A and B, sample BLII_B, both detailed in Table 1. SIMS was performed after the annealing and oxidation step, and ECV was performed after an additional $\mathrm{HF}$ dip. $\mathrm{SiO}_{2}$ thickness is represented with the hatched area, and the SIMS of the BLII_asImp sample was added in B, for comparison along with the boron solubility limit at $950^{\circ} \mathrm{C}$ as a dot line at $9 \times 10^{19} / \mathrm{cm}^{3}$ [Colour figure can be viewed at wileyonlinelibrary.com]

a)

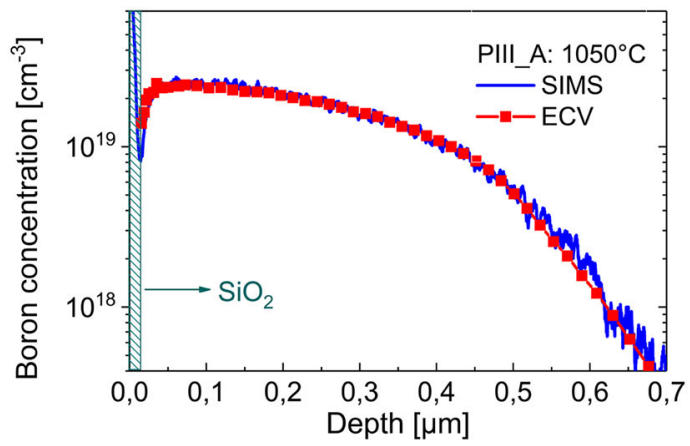

b)

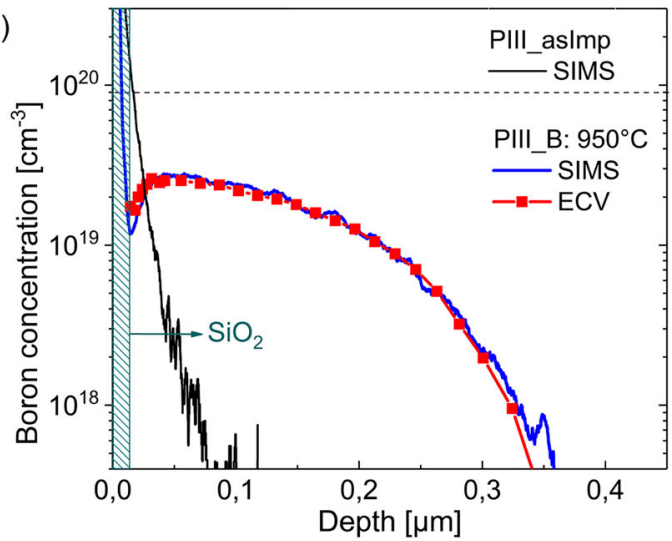

FIGURE 3 Boron concentration measured by secondary-ion mass spectroscopy (SIMS) and activated boron concentration obtained by electrochemical capacitance voltage (ECV) measurement of A, sample PIII_A and B, sample PIII_B, both detailed in Table 1. SIMS was performed after the annealing and oxidation step, and ECV was performed after an additional $\mathrm{HF}$ dip. $\mathrm{SiO}_{2}$ thickness is represented with the hatched area. The SIMS measurement of the PIII_asImp sample was added in B, for comparison along with the boron solubility limit at $950^{\circ} \mathrm{C}$ as a dot line at $9 \times 10^{19} / \mathrm{cm}^{3}$ [Colour figure can be viewed at wileyonlinelibrary.com]
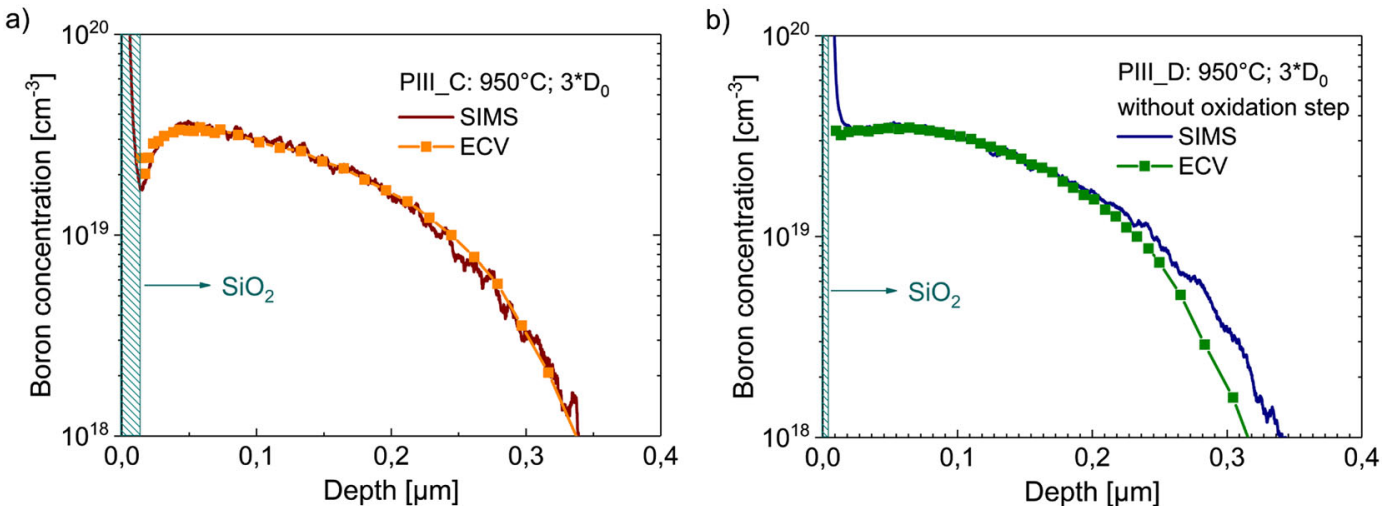

FIGURE 4 Boron concentration measured by secondary-ion mass spectroscopy (SIMS) and activated boron concentration obtained by electrochemical capacitance voltage (ECV) measurement of A, sample PIII_C and B, sample PIII_D, both detailed in Table 1. SIMS was performed after the annealing and oxidation step, and ECV was performed after an additional $\mathrm{HF}$ dip. $\mathrm{SiO}_{2}$ thickness is displayed with the hatched area [Colour figure can be viewed at wileyonlinelibrary.com] 
a)

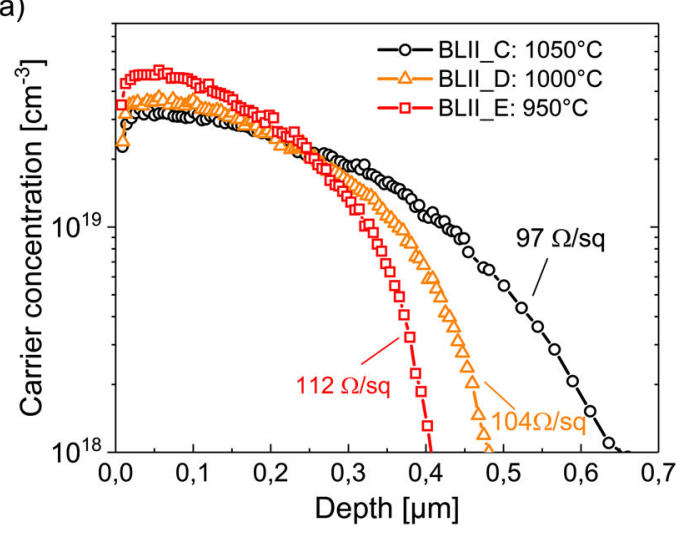

b)

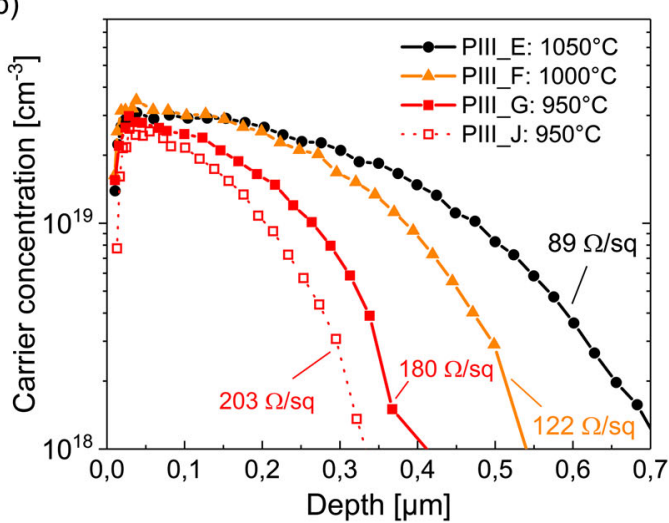

FIGURE 5 Electrochemical capacitance voltage (ECV) measurements of A, beamline ion implantation (BLII) and B, plasma-immersion ion implantation (PIII) boron-doped emitters annealed at $950^{\circ} \mathrm{C}(30 \mathrm{~min}), 1000^{\circ} \mathrm{C}(15 \mathrm{~min})$, and $1050^{\circ} \mathrm{C}(5 \mathrm{~min})$, with corresponding sheet resistances. The case of PIII_J emitter annealed at $950^{\circ} \mathrm{C}$ and further etched is added in $\mathrm{B}$, [Colour figure can be viewed at wileyonlinelibrary.com]

a)

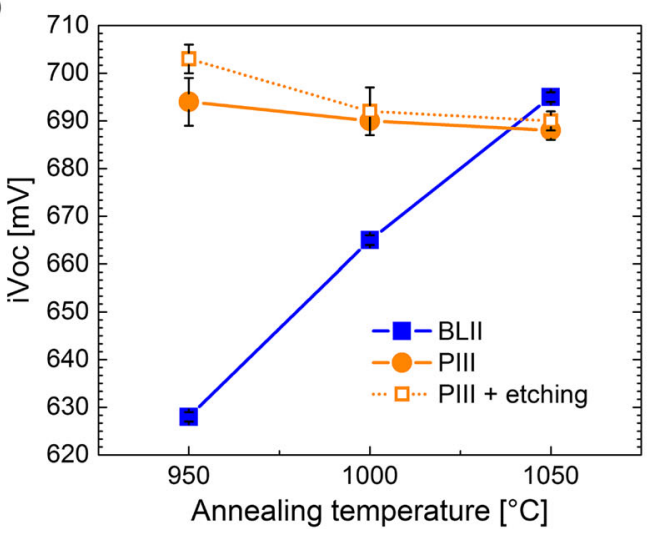

b)

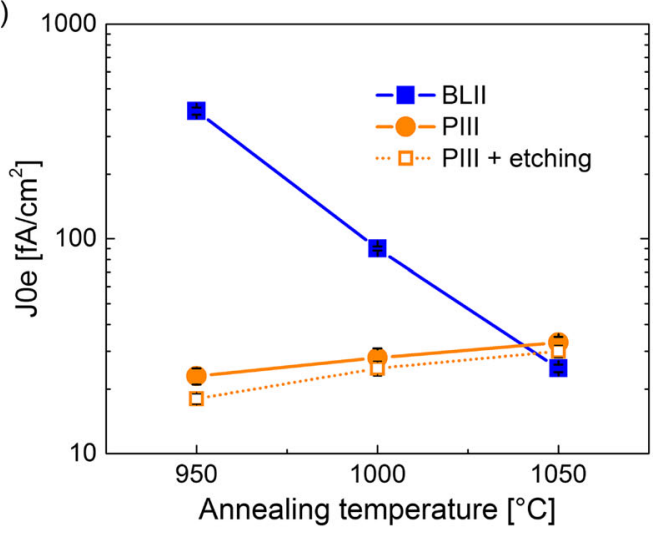

FIGURE $6 \mathrm{~A}, \mathrm{iV}_{\mathrm{oc}}$ and $\mathrm{B}, \mathrm{J}_{\mathrm{Oe}}$ average and distribution determined on the boron-implanted emitters detailed in Table 2. Plasma-immersion ion implantation (PIII) and beamline ion implantation (BLII) comparison for annealing at $1050^{\circ} \mathrm{C}(5 \mathrm{~min}), 1000^{\circ} \mathrm{C}(15 \mathrm{~min})$, or $950^{\circ} \mathrm{C}(30 \mathrm{~min})$ using an $\mathrm{Al}_{2} \mathrm{O}_{3} / \mathrm{SiN}_{x}$ passivation, with or without an additional 50 - to $60-\mathrm{nm}$ etching step in the PIII case

a)

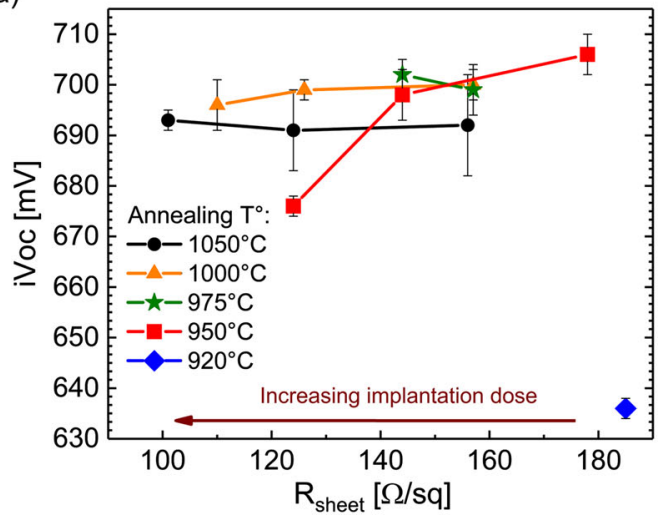

b)

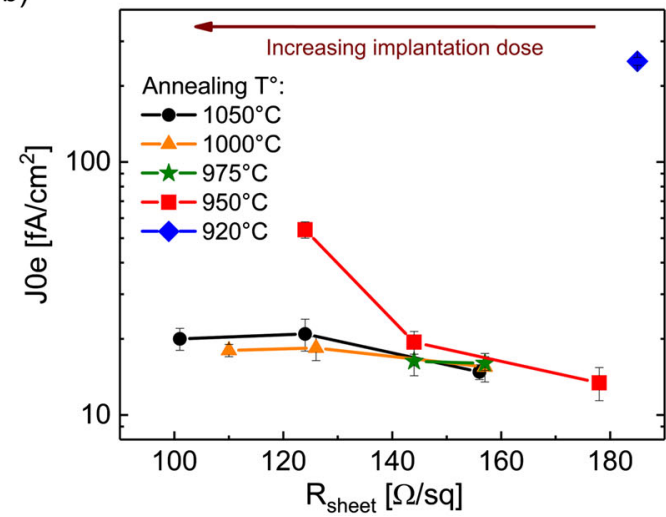

FIGURE 7 (A) $\mathrm{iV}_{\mathrm{oc}}$ and $(\mathrm{B}) \mathrm{J}_{\mathrm{Oe}}$ average values of plasma-immersion ion implantation (PIII) boron emitters annealed at various annealing peak temperatures and time with $\mathrm{Al}_{2} \mathrm{O}_{3} / \mathrm{SiN}_{\mathrm{x}}$ passivation. Several implantation doses were used increasing from $0.8 \times 10^{15}$ to $5.5 \times 10^{15}$ at/ $\mathrm{cm}^{2}$

[Colour figure can be viewed at wileyonlinelibrary.com] 
used while deactivating the "SRH-at-surface" and "SRH-in-emitter" module. Simulation results are shown in Table 3. The Joe only due to Auger recombination increases from 9.0 to $16.8 \mathrm{fA} / \mathrm{cm}^{2}$ when the implantation dose increases from $2.0 \times \mathrm{D}_{0}$ to $5.5 \times \mathrm{D}_{0}$. However, the $J_{0 e}$ increase due to Auger recombination only represents $19.0 \%$ of the total $\mathrm{J}_{\mathrm{Oe}}$ increase (increase from 13 to $54 \mathrm{fA} / \mathrm{cm}^{2}$ ). Therefore, $81.0 \%$ of the $J_{0 e}$ increase would be related to Shockley-Read-Hall (SRH) recombination in the emitter or at the surface, likely to be due to remaining implantation damages for the high implantation dose.

Finally, the PIII boron-doped emitter annealed at $920^{\circ} \mathrm{C}$ exhibits a very high $\mathrm{J}_{\mathrm{O}}$ value above $200 \mathrm{fA} / \mathrm{cm}^{2}$ for a sheet resistance of 185 $\Omega /$ sq, which is not suitable for solar cells processing, and suggests stable BICs formation in the emitter.

A good correlation of the $\mathrm{i}_{\mathrm{oc}}$ results with the $\mathrm{J}_{\mathrm{Oe}}$ values is seen in Figure 7 with a strong degradation of the $\mathrm{i}_{\text {oc }}$ at $920^{\circ} \mathrm{C}$ and lower performances of the $\mathrm{i}_{\mathrm{oc}}$ for the highest dose used with the annealing at $950^{\circ} \mathrm{C}$. Lower $\mathrm{iV}_{\text {oc }}$ performances are measured at $1050^{\circ} \mathrm{C}$ as compared with $1000^{\circ} \mathrm{C}$ and $975^{\circ} \mathrm{C}$ anneals that could result from a bulk carrier lifetime deterioration due to the high-thermal budget. This hypothesis is supported by a decrease of the estimated bulk lifetime extracted from the IC-QssPC measurements, from 700 to $580 \mu \mathrm{s}$ when the annealing temperature increases from $1000^{\circ} \mathrm{C}$ to $1050^{\circ} \mathrm{C}$. The $\mathrm{i}_{\text {oc }}$ decrease highlights the necessity to lower the annealing temperature below $1050^{\circ} \mathrm{C}$ to avoid the bulk degradation and thus reach higher efficiencies.

At last, the effect of the oxidation step during the activation annealing on the emitter quality was investigated in Table 4. For each annealing peak temperature, a slight increase of the $R_{\text {sheet }}$ is measured with the oxidation step, which is explained by the emitter consumption during the $\mathrm{SiO}_{2}$ growth (see Figure 4 that illustrates the impact on the $[\mathrm{B}]$ profile).

Results exhibit lower $\mathrm{iV}_{\mathrm{oc}}$ values on the PIII boron-doped emitter when the oxidation step is removed, with drops between 8 and 25 $\mathrm{mV}$. Similarly, $\mathrm{J}_{\mathrm{Oe}}$ values slightly increase without the oxidation but remain very low for the $1050^{\circ} \mathrm{C}$ and $1000^{\circ} \mathrm{C}$ cases. At $950^{\circ} \mathrm{C}$ however, the $J_{0 e}$ value of PIII_ $\gamma 2$ strongly increases without oxidation and exceeds $160 \mathrm{fA} / \mathrm{cm}^{2}$, which is consistent with the inactive boron dose observed in the PIII boron emitter annealed at $950^{\circ} \mathrm{C}$ in Figure $4 \mathrm{~B}$. Therefore, the oxidation step is always beneficial and becomes necessary if the annealing temperature is reduced down to $950^{\circ} \mathrm{C}$.

\section{3 | Integration of PIII boron emitter in n-type PERT solar cells}

\subsection{1 | Contact by screen printing}

The contact resistivity determined on the PIII boron-doped emitter after the screen printing and firing of a commercial $\mathrm{Ag} / \mathrm{Al}$ paste was investigated on all the PIII emitters from Table 2. Results shown in Table 5 confirm a good contact resistivity (below $6 \mathrm{~m} \Omega . \mathrm{cm}^{2}$ ) in all cases even for boron emitter sheet resistances of $180 \Omega$ /sq with sample PIII_G and of $203 \Omega$ /sq for PIIIJ.

\subsection{2 | Full PIII-implanted n-type PERT solar cells}

In this section, the PIII boron-doped emitters annealed at low temperature $\left(950^{\circ} \mathrm{C}\right.$ and $\left.1000^{\circ} \mathrm{C}\right)$ were integrated in full PIII n-PERT

TABLE 5 Average contact resistivity measured on six batches of PIII boron emitters detailed in Table 2

\begin{tabular}{llccc} 
Name & Implant & Annealing Temperature $\left({ }^{\circ} \mathrm{C}\right)$ & Etching & No $\left(\mathrm{m} \Omega . \mathrm{cm}^{2}\right)$ \\
PIII_E & PIII: $\mathrm{B}_{2} \mathrm{H}_{6}$ & 1050 & No & 2.4 \\
PIII_F & PIII: $\mathrm{B}_{2} \mathrm{H}_{6}$ & 1000 & No & 2.7 \\
\hline PIII_G & PIII: $\mathrm{B}_{2} \mathrm{H}_{6}$ & 950 & Yes & 4.4 \\
PIII_H & PIII: $\mathrm{B}_{2} \mathrm{H}_{6}$ & 1050 & Yes & 2.7 \\
PIII_I & PIII: $\mathrm{B}_{2} \mathrm{H}_{6}$ & 1000 & Yes & 5.7 \\
PIII_J & PIII: $\mathrm{B}_{2} \mathrm{H}_{6}$ & 950 & & 5.6 \\
\hline
\end{tabular}

Abbreviation: PIII, plasma-immersion ion implantation.

TABLE 6 I(V) parameters of champion n-PERT solar cells fully doped by PIII using the separate anneals and coanneal processes

\begin{tabular}{|c|c|c|c|c|c|c|}
\hline Process & $\begin{array}{l}\text { Boron Annealing } \\
\text { Temprature }\left({ }^{\circ} \mathrm{C}\right)\end{array}$ & Emitter $R_{\text {sheet }}(\Omega / s q)$ & $\mathrm{V}_{\text {oc }}(\mathrm{mV})$ & $\mathrm{J}_{\mathrm{sc}}(\mathrm{mA} / \mathrm{cm} 2)$ & $\mathrm{FF}(\%)$ & $\eta(\%)$ \\
\hline Separated anneals-batch 1 & 1000 & 110 & $660^{a}$ & $39.3^{a}$ & $79.4^{a}$ & $20.6^{\mathrm{a}}$ \\
\hline & 950 & 122 & 662 & 39.5 & 79.0 & 20.7 \\
\hline Coanneal-batch 2 & 950 & 115 & 660 & 39.5 & 79.2 & 20.7 \\
\hline
\end{tabular}

Note. The corresponding $\mathrm{R}_{\text {sheet }}$ of the boron emitter is also indicated.

Abbreviations: PERT, passivated emitter rear totally diffused; PIII, plasma-immersion ion implantation.

${ }^{a}$ Measure independently confirmed at CalTec. 
solar cells. The complete industrial process flows noted as separated anneals and detailed above were used for these cells, with twosuccessive batches. For the first batch (batch 1), a single-layer antireflective coating was used as well as a nonspecifically optimized metallization grid, leading to large fingers widths of 50 to $55 \mu \mathrm{m}$ after firing. The second (batch 2) includes improvements on the metallization process (with finger widths of $45 \mu \mathrm{m}$ after firing) and a double-layer antireflective coating. Champion cells $\mathrm{I}(\mathrm{V})$ parameters of each process are reported in Table 6.

In the first batch, a maximum efficiency of $20.6 \%$ (independently confirmed by (alTec) was measured using two anneals to separately activate boron and phosphorus dopants with an annealing temperature below $1050^{\circ} \mathrm{C}$ for the boron activation. The high performance of the boron emitter annealed at $1000^{\circ} \mathrm{C}$ is supported by the high open-circuit voltage $\left(\mathrm{V}_{\text {oc }}\right)$ value of $660 \mathrm{mV}$ and the efficiency of $20.6 \%$ close to the current n-PERT performances found in pilot lines. ${ }^{3}$ As the efficiency is mainly limited on these cells by the short-circuit current density $\left(\mathrm{J}_{\mathrm{sc}}\right)$, work on the metallization grid was performed to increase this parameter with batch 2 .

In batch 2, two annealing temperatures were compared for the boron activation, $1000^{\circ} \mathrm{C}$ and $950^{\circ} \mathrm{C}$, leading to boron emitter $R_{\text {sheet }}$ of 100 and $122 \Omega /$ sq, respectively. At $1000^{\circ} \mathrm{C}$, the boron emitter corresponds to a $\mathrm{J}_{\mathrm{Oe}}$ value of $22 \mathrm{fA} / \mathrm{cm}^{2}$, measured on symmetrical samples. In that case, solar cell results show a maximum efficiency of $20.8 \%$ because of the improvement of the $V_{\text {oc }}$ up to $665 \mathrm{mV}$ and of the $J_{\mathrm{sc}}$. This $J_{\mathrm{sc}}$ value is expected to increase even further with additional optimization of the metallization process. The use of a lower anneal temperature of $950^{\circ} \mathrm{C}$ in this separated anneals process leads to similar performance to the $1000^{\circ} \mathrm{C}$ anneal with a maximum solar cell efficiency of $20.7 \%$, despite an expected slight increase of the $J_{0 e}$ value just as observed in Figure 7B for this $R_{\text {sheet }}$ of 122 $\Omega /$ sq. This is an important result that confirms the above study at the solar cell scale, especially the $V_{\text {oc }}$ value above 660 $\mathrm{mV}$ demonstrates the possibility to anneal boron-implanted emitters at $950^{\circ} \mathrm{C}$ while using PIII implantation from $\mathrm{B}_{2} \mathrm{H}_{6}$ plasma.

In addition, solar cells were processed with a single annealing at $950^{\circ} \mathrm{C}$ to activate both dopants. Result of this coanneal process shows for the first time similar performances than the separated anneals cells, with the same maximum efficiency of $20.7 \%$, contrary to previous work where lower efficiencies were reported with the coannealed process at $1050^{\circ} \mathrm{C}^{7}$ Therefore, lowering the activation temperature down to $950^{\circ} \mathrm{C}$ not only avoids bulk carrier lifetime degradations from high-thermal treatments but also increases the efficiency potential of this ultrasimplified co-anneal process flow. Combined with the reduced production cost of the PIII technique, this process becomes a promising candidate for n-PERT solar cells fabrication.

\section{4 | CONCLUSION}

We report on a new way of activating the implanted boron emitter at temperatures below $1050^{\circ} \mathrm{C}$ based on the use of PIII from $\mathrm{B}_{2} \mathrm{H}_{6}$ plasma instead of the standard BLII of $\mathrm{B}^{+}$ions. Because of the differences in the as-implanted profile (maximum concentration of boron located at the surface in PIII), PIII boron-doped emitters without implantation damages and boron clusters were obtained with annealing temperature down to $950^{\circ} \mathrm{C}$. A full activation of the emitter at $950^{\circ} \mathrm{C}$ was observed even for a high implantation dose corresponding to a sheet resistance of $112 \Omega /$ sq. The results also highlight the important role of the oxidation step subsequent to the activation annealing to avoid the presence of inactive boron atoms in the emitter. At $1000^{\circ} \mathrm{C}$, J $\mathrm{J}_{\mathrm{e}}$ below $21 \mathrm{fA} / \mathrm{cm}^{2}$ was obtained using the PIII technique regardless of the implantation dose for sheet resistances between 110 and $160 \Omega / s q$, while $J_{0 e}$ increases above $85 \mathrm{fA} / \mathrm{cm}^{2}$ for BLIl emitter of $104 \Omega / \mathrm{sq}$. The PIII boron emitters show promising performances while being integrated into n-PERT solar cells fully doped by PIII with efficiency of $20.6 \%$ independently confirmed. Furthermore, an efficiency of $20.7 \%$ was obtained with an ultrasimplified $n$-PERT process flow, including two low-cost PIII implantations and a single coannealing at $950^{\circ} \mathrm{C}$.

\section{ACKNOWLEDGEMENTS}

The authors would like to thank E. De Vito from CEA Leti for the SIMS measurements and analyses and the Bpifrance and FUI for their financial support through the French ISICELL project.

\section{ORCID}

Adeline Lanterne (D) https://orcid.org/0000-0001-8080-2545

\section{REFERENCES}

1. Min B, Muller M, Wagner $\mathrm{H}$, et al. A roadmap toward $24 \%$ efficient PERC solar cells in industrial mass production. IEEE J Photovoltaics. 2017;7(6):1541-1550.

2. "International Technology Roadmap for Photovoltaic (ITRPV) 2016 results including maturity report," www.itrpv.net, no. September, 2017.

3. Buchholz F, Preis P, Chu H, Lossen J, Wefringhaus E. Progress in the development of industrial nPERT cells. Energy Procedia. 2017;124:649-656

4. Ryu K, Cho E, Rohatgi A, Ok Y-W. Process development and comparison of various boron emitter technologies for high-efficiency ( 21\%) ntype silicon solar cells. Prog Photovolt Res Appl. 2016;24(8):1109-1115.

5. Das A, Ryu K, Rohatgi A. 20\% efficient screen-printed n-type solar cells using a spin-on source and thermal oxide/silicon nitride passivation. IEEE J Photovoltaics. 2011;1(2):146-152.

6. Lim B, Brendemuhl T, Dullweber T, Brendel R. Loss analysis of n-type passivated emitter rear totally diffused back-junction silicon solar cells with efficiencies up to 21.2\%. IEEE J Photovoltaics. 2016;6(2):447-453.

7. Kiefer $F$, Krügener J, Heinemeyer F, et al. Bifacial, fully screen-printed n-PERT solar cells with BF2 and B implanted emitters. Sol Energy Mater Sol Cells. 2016;157:326-330.

8. Wei Q, Zhang S, Yu S, Lu J, Lian W, Ni Z. High efficiency n-PERT solar cells by B/P co-diffusion method. Energy Procedia. 2017;124:700-705.

9. Ryu K, Madani K, Rohatgi A, Ok YW. High efficiency screen-printed ntype silicon solar cell using co-diffusion of APCVD boron emitter and POCI3 back surface field. Curr Appl Phys. 2018;18(2):231-235.

10. Low RJ, Gupta A, Bateman N, et al. "High efficiency selective emitter enabled through patterned ion implantation," 35th IEEE Photovolt. Spec. Conf., pp. 1440-1445, 2010. 
11. Rohatgi A, Meier DL, McPherson B, et al. High-throughput ionimplantation for low-cost high-efficiency silicon solar cells. Energy Procedia. 2012;15:10-19.

12. Krügener J, Peibst R, Bugiel E, et al. Ion implantation of boric molecules for silicon solar cells. Sol Energy Mater Sol Cells. 2015;142:12-17.

13. Aboy M, Santos I, Pelaz L, Marqués LA, López P. Modeling of defects, dopant diffusion and clustering in silicon. J Comput Electron. 2014;13(1):40-58.

14. Raghuwanshi M, Lanterne A, le Perchec J, et al. Influence of boron clustering on the emitter quality of implanted silicon solar cells: an atom probe tomography study. Prog Photovoltaics Res Appl. 2015;23(12):1724-1733.

15. Müller R, Benick J, Bateman N, et al. Evaluation of implantation annealing for highly-doped selective boron emitters suitable for screenprinted contacts. Sol Energy Mater Sol Cells. 2014;120:431-435.

16. Müller R, Moldovan A, Schiller C, Benick J. Defect removal after low temperature annealing of boron implantations by emitter etch-back for silicon solar cells. Phys Status Solidi-Rapid Res Lett. 2015;9(1):32-35.

17. Desrues T, Michel T, Lerat JF, et al. "High quality industrial phosphorus emitter doping obtained with innovative plasma immersion ion implantation (PIII) processes," Proceeding 33rd Eur. Photovolt. Sol. Energy Conf. Exhib. Amsterdam, pp. 960-962, 2017.

18. Michel T, le Perchec J, Lanterne A, et al. Phosphorus emitter engineering by plasma-immersion ion implantation for c-Si solar cells. Sol Energy Mater Sol Cells. 2015;133:194-200.

19. Kimmerle A, Rothhardt $P$, Wolf $A$, Sinton RA. Increased reliability for $J_{0}$-analysis by QSSPC. Energy Procedia. 2014;55:101-106.

20. Richter A, Glunz SW, Werner F, Schmidt J, Cuevas A. Improved quantitative description of Auger recombination in crystalline silicon. Phys Rev B. 2012;86(16):165202.
21. Schenk A. Finite-temperature full random-phase approximation model of band gap narrowing for silicon device simulation. J Appl Phys. 2013;84(7):3684.

22. Reeves GK, Harrison HB. Obtaining the specific contact resistance from transmission line model measurements. IEEE Electron Device Lett. 1982;3(5):111-113.

23. De Salvador D, Napolitani E, Bisognin G, et al. Dissolution kinetics of B clusters in crystalline Si. Mater Sci Eng B Solid-State Mater Adv Technol. 2005;124-125:32-38.

24. Nobili D. "Properties of silicon," EMIS Datareviews Ser. No. 4 New York INSPEC, pp. 384-385, 1988.

25. Packan P. Thompson S, Andideh E, et al. "Modeling solid source boron diffusion for advanced transistor applications," IEDM Tech. Dig., San Fr. CA, USA, pp. 505-508, 1998.

26. Lanterne A, Gall S, Veschetti $Y$, et al. High efficiency fully implanted and co-annealed bifacial n-type solar cells. Energy Procedia. 2013;38:283-288.

27. "PV Lighthouse," www.pvlighthouse.com.au, 2018.

28. Richter A, Glunz SW, Werner F, Schmidt J, Cuevas A. Improved quantitative description of Auger recombination in crystalline silicon. Phys Rev B-Condens Matter Mater Phys. 2012;86(16):165202.

How to cite this article: Lanterne A, Desrues T, Lorfeuvre C, et al. Plasma-immersion ion implantation: A path to lower the annealing temperature of implanted boron emitters and simplify PERT solar cell processing. Prog Photovolt Res Appl. 2019;1-11. https://doi.org/10.1002/pip.3186 